\title{
Financial Development and Economic Growth: Evidence from Lebanon
}

\author{
Wadad Saad ${ }^{1}$ \\ ${ }^{1}$ Department of Economics, Faculty of Economics and Business Administration, Lebanese University, Hadath, \\ Lebanon \\ Correspondence: Wadad Saad, Department of Economics, Faculty of Economics and Business Administration, \\ Lebanese University, Hadath, Lebanon. Tel: 961-3-880-036. E-mail: wsaad@ul.edu.lb
}

Received: May 23, 2014

doi:10.5539/ijef.v6n8p173
Accepted: May 28, 2014

Online Published: July 25, 2014

URL: http://dx.doi.org/10.5539/ijef.v6n8p173

\begin{abstract}
The objective of this study is to determine whether a relationship exists between financial development and economic growth in Lebanon. The investigation of this link is carried out within a VECM framework over the period 1972-2012. This study uses the VECM-based Granger-causality test to provide empirical evidence of the causal relationship between financial development and economic growth. The evidence suggests that the credit market is still underdeveloped in this country and its contribution to economic growth is limited owing to a lack of financial depth. Therefore, the focus is on the banking sector to measure the financial development. The findings indicate the presence of a positive relationship between financial development and economic growth in the short run that is accompanied by bidirectional Granger causality between these variables. However this relationship is found to be insignificant in the long run. Moreover, the results indicate that the efficiency of the banking sector has an important role in the Lebanese economic growth.
\end{abstract}

Keywords: financial development, economic growth, VECM methodology, causality tests

\section{Introduction}

The reform of the financial sector in Lebanon started from the banking sector. After a long period of civil war and political events that took place from 1975 to 1989, many regulations and reforms have been introduced since 1993 that made the banking sector turn rapidly into one of the most dynamic sector of the economy. The reform process and the implementation of a variety of financial innovations in the Lebanese banking sector have helped to enhance the economy in general but this sector is still has to face various challenges deriving mostly from the unstable political and economic situation that dominates on the country.

This study explores the relationship between financial development and economic growth for Lebanon over the period 1972-2012. The importance of this study stems from the fact that if a relationship between financial development and economic growth exists and the direction of causality is from financial development to economic growth, then this economy can enhance its growth by developing its financial system. However, previous studies have reported a variety of results going from unidirectional causality to bidirectional one, and others have indicated that the direction of causality is from economic growth to financial development only (Levine, 1997).

The methodology used in this study consists of employing the Vector Error Correction Model (VECM) to investigate the presence of long run and short run relationship between variables representing the financial sector growth and economic growth, using annual data for period going from 1972 to 2012 . Then Granger causality tests, that indicate the direction between these variables, are examined through the VECM model.

This paper will be organized as follows: section 2 describes the economic situation in Lebanon during the sample period. Section 3 provides the main features of the Lebanese banking sector. Section 4 is devoted to literature review. As to the methodology, it is explained in section 5. The data and variable description is presented in section 6 . In section 7 the results are reported and analyzed. The final section concludes the study.

\section{Economic Situation in Lebanon (Note 1)}

Before 1975, Lebanon was considered as a banking center for the Middle East. Its liberal economic system and deregulated framework motivated entrepreneurial activity and innovation. Moreover, its advanced educational 
system and its connection with the west, accompanied by a stable banking system, make Lebanon to play the role of intermediary between the Arab countries and the rest of the world.

The outbreak of the civil war in Lebanon was in 1975. This war lasted till 1989 and severely damaged civilian infrastructure and the economy and caused a large destruction at all levels. In 1983, Lebanon entered serious economic recession. Economic activity declined, capital inflows dropped, the budget deficit widened, and the Lebanese pound's exchange rate collapsed. As a result, Lebanon gradually lost his position as a financial centre and as a warehouse for funds.

Historically, Lebanon used to be a model for social and economic development in the region until 1975 when a 15-year civil war destroyed the infrastructure and severely damaged the economy. Although, post-war policies for reconstruction and rehabilitation during 1990's were relatively successful, but did not achieve what was expected and aggravated the political and economic situation. Public debt and deficit increased rapidly due to a large expansionary government expenditure policy. Many governments and international organizations such World Bank Group insured billions of dollars to support financially the Lebanese government during the Paris 1, Paris II, and Paris III conferences in 2001, 2002 and 2007 respectively.

The implementation of the program of construction didn't come with the desired results since it was hampered by several political disruptions and mismanagement of the reforms.

The major financial problem that faces Lebanon is its huge public debt that reached $180 \%$ of GDP in 2006 and considered among the highest in the world (Note 2). The Lebanese banks held about $80 \%$ of the public debt at that time. Later, these banks were much more capable of absorbing local shocks than were before due to high oil prices that resulted in significant capital inflows from the Golf countries. These inflows were translated in waves of new loans to the domestic private sector and were responsible for $70 \%$ of the GDP growth considered in the period 2007-2010.

After 4 years of high economic growth, the Lebanese economy started declining since 2011 affected by the internal political situation compounded with the regional turbulence. However, the debt to GDP ratio has started to decline since 2006. Although the amount of public debt continued to increase consistently, but the ratio of the debt to GDP decreased to $143.87 \%$ and $124.94 \%$ in 2011 and 2012 respectively. With respect to the domestic and foreign debt, the local currency debt was about $61 \%$ of the total public debt and the foreign currency debt was $39 \%$ in 2011. These proportions changed in 2012, the domestic currency debt registered $57.72 \%$ of the gross public debt and the foreign currency debt reached $42.28 \%$.

The economic growth dropped from about 8\% during the period $2007-2010$ to $1.6 \%$ and $1.5 \%$ in 2011 and 2012 respectively. The economic recession as of 2011, translated by regression of demand for exports, as well as tourism and real estate activities, led to a slowdown in credit demand and therefore a decline in lending rates. Although the legislation is liberal in Lebanon in terms of not differentiating between domestic and foreign investor, investors have been always suffering from the weight of bureaucracy and the outdated regulations that need a lot of modernization.

Lebanon's economy is service-oriented and mostly based on financial services, trade, and tourism. The Lebanese economy is highly dependent on the services sector which makes it more vulnerable to external shocks beside the internal ones. The global economic recession and the national and regional events that took place had its negative repercussions on the Lebanese economic growth during 2011-2012. This situation was translated by regression of demand for exports, as well as tourism and real estate activities.

\section{Lebanese Banking Sector (Note 3)}

Nowadays, Lebanon's banking sector encompasses 64 commercial banks, including 11 specialized institutions and four Islamic banks. The five largest banks account for more than $60 \%$ of the total banking sector's assets. The Lebanese banking sector enjoys several characteristics that promote the role of Beirut as a regional financial center, in terms of earnings and ensuring protection for foreign capital. These characteristics go from free exchange system to free capital and earning movement and banking secrecy law, among others. Before 1975, Lebanon was considered as a banking center for the Middle East.

The banking sector showed relatively good performance during the civil war that lasted from 1975 to 1989 . This indicated a certain flexibility and capacity to cope with events. This environment provided a strong incentive for some Lebanese banks to operate abroad, mainly in Europe. They succeeded to open branches abroad and capture some deposits held by Lebanese living abroad.

In the post war period, the government launched a series of reforms and deregulations that were assumed to enhance the role of the capital markets in the economic growth and for Lebanese banks to face the challenge and 
competitiveness at the international levels. However, this process was interrupted many times by major political events that hampered relatively its advancement. In spite of all these impeding circumstances, the financial sector has shown significant resilience that helped it to stay as competitive player with its peer neighbors in the region. The main pillars of the Lebanese banking system are its liquidity and solvability. Moreover, the secrecy law that dominates the banking accounts makes it attractive to Gulf countries depositors. It is important to mention that in the first decade of the post war period about thirty banks merged with bigger peers or taken over. This acquisition and merging policy was encouraged by the central bank and the financial authorities. This consolidation had preceded the implementation of Basel II capital regulations that started in 2008.

Although surrounded by ongoing political crises and several wars, the Lebanese banking sector have ridden out of these circumstances, including the 2008 financial crisis. The Lebanese banks have been always a crucial source of funds for the government in order to finance the consecutive increasing deficits. They have lived well by investing in high yielding treasury bonds and avoiding high risk investment abroad. More than $50 \%$ of the public debt is held by Lebanese commercial Banks.

The period between 2008 and 2010 was exceptional for the Lebanese economy and banking sector. Backed by an economic growth rate averaging $8.5 \%$ a year and a stable banking sector, Lebanon benefited from the global disturbance by attracting significant capital inflows which have translated into important waves of new loans to the domestic private sector. This situation spurred high economic growth rates during that period. In fact, banks have been driven by deposits from residents and non-residents (Lebanese Diaspora) who were attracted by the high returns available and longstanding family and community ties. Moreover, the boom liquidity in the Gulf countries, at that period, due to high prices of oil accompanied by the decision of financial authorities to keep domestic interest rates high while global rates dropped were also the other factors that played a key role in the increase in deposits. These letter grew by more than $23 \%$ in 2009 , compared to $11 \%$ in 2007 . This situation allowed the central bank to increase its international reserves to over US\$29 billion. However, the annual growth rate of deposit inflows declined slightly in 2010 to reach about $11 \%$ after a series of interest cuts.

Thus, during that period, the Lebanese's financial and banking sector not only has been unaffected by the ongoing national and international crises, but also proved to be a competitive player in reinvesting the important Gulf region's liquidity. The Central Bank has been always in charge of monetary policy, including exchange rate policy and determining the interest rate ceilings.

It is important to mention that Lebanese banks have started to implement Basel III capital requirements at the end of 2012. All banks should have complied with these requirements by the end of 2015 (Note 4).

\section{Literature Review}

The impact of financial development on economic growth is a controversial issue on both empirical and theoretical framework. Apergis et al (2007) classified this matter into four schools of thought. The first one is denoted as supply-leading view which was first analyzed by Schumpeter (1912) and John Hicks (1969). They noticed that the prosperity and evolution of the economies in certain countries were backed up by the capacity of financial systems to activate the productivity of the financial capital. Later on, Levine (1997) pointed out that the development of the financial sector, with its two components stock markets and institutions, plays a remarkable role in the economic growth. Cline (2010) argues that the improvement in the financial sector will lead to an enhancement of the various sectors of the economy. Besides, the endogenous growth literature is in line with this point of view and assumes that the government intervention in the financial system (such as high reserve requirement, interest rate ceilings, etc) has a negative impact on the economic growth.

The second school adopts the demand following view which stipulates that the financial development is a response of the real changes in the economy (see Robinson, 1952, p. 86). This point of view indicates that the lack of financial growth stems from the lack of demand of financial services. Odhiambo (2009) found, in a study about the causality between finance and growth in South Africa, that this relationship was taking a demand-following path. Similarly, Zang and Kim (2007) employed panal analysis on 74 countries and showed that the direction of causality was from economic growth to financial development. The third school assumes that there is a mutual effect between finance and growth. The feedback effect was found by several researchers such as Luintel and Khan (1999) who used multivariate vector autoregression analysis to explore the finance-growth nexus in ten less developing countries. The findings indicate bidirectional causality between financial development and growth. As to the fourth point of view suppose that there is no relationship between financial development and economic growth. Moreover, Lucas (1988) revealed that the role of finance was exaggerated in explaining the economic growth.

A host of studies has examined the effect of financial development on economic growth. The exploration of this 
relationship has been approached with a variety of methods. Some of these studies used cross-country regressions, others employed panel data, and many used time-series analysis.

Goldsmith (1969) employed a cross-country regression and revealed the presence of a positive relationship between financial system and economic growth. Levine (2005) revealed some critics concerning Goldsmith's work by stating that the sample used was small (34 countries) and there was no investigation of the causality direction. In 1993 King and Levine ameliorated the work of Goldsmith by enlarging the sample size (77 countries) and by introducing control variables in the model. They found a strong positive relationship between finance and growth, but still they didn't investigate the causality issue and focused only on the banking sector. However, in 1996 Levine and Zervos used a cross country regression that encompassed 42 countries and added the stock market as an indicator of financial development among others. They found that the involved financial indicators were positively correlated with economic growth after using other controlling variables that could impact growth. Beside some critics concerning the choice of the financial indicators, this study didn't also examine causality issue.

Panel data have been employed in several studies to explore the relationship between finance and economic growth. Levine et al. (2000) apply a panel GMM method for this purpose and Beck et al. (2000) use panel data in their study. Both papers found a positive relationship between finance and growth.

Time series techniques have been also used to investigate the finance-growth relationship, especially vector error correction methodology (VECM) and Granger causality tests. Demetriades and Hussein (1996) found bidirectional causality between finance to growth in developed countries. Arestis et al. (2001) assess the relationship between finance and growth using a sample of developing countries and focusing on both stock markets and banks. They indicate a positive and significant link between finance and growth and they notice a larger impact form banking sector. Christopoulos and Tsionas (2004) use panel cointegration analysis and find a long run causality that runs from finance to growth.

The time series studies concerning Mediterranean countries include two types: country and cross-country studies. As to country studies, Ghali (1999) in a study about the relationship between finance and growth in Tunisia that includes the ratio of money to GDP, ratio of M2 minus currency to GDP, ratio of bank credit to private sector to GDP, and ratio of credit to private sector to total domestic credit, as indicators of financial development. He finds bidirectional causality between financial development and economic growth.

In a study about the finance-growth nexus in Turkey, Kar and Pentecost (2000) use VECM and Granger causality and find that the direction of the causality depends on the financial development used. They show that the causality runs from finance to growth when the money to income ratio is employed, while it runs from growth to finance when bank deposits, private credit and domestic credit ratios are used.

Among the multi-country studies, there is a study done by Abu-Bader and Abu-Qarn (2008) that assesses the causal relationship between finance and growth for six countries (Algeria, Egypt, Israel, Morocco, Syria, and Tunisia). Using five financial development indicators, they find that finance leads growth in five countries (Algeria, Egypt, Morocco, Syria, and Tunisia).

However, some studies showed no relationship between finance and growth. For instance, Ben Naceur et al. (2008) examine the finance-growth relationship in eleven Southern Mediterranean countries over the period 1979-2005 using GMM model and find that there is no effect on growth.

Furthermore, Achy (2005) explores the impact of financial development on growth, using panel GLS method for a sample of five countries of Southern Mediterranean countries over the period 1970-1999, and finds that there no significant relationship with growth.

\section{Methodology}

This study investigates the impact of financial development (FD) and a variety of macroeconomic variables on the economic growth in Lebanon. The suggested econometric model can be expressed as:

$$
\text { Log real GDP per capita }=\alpha+\beta F D_{t}+\gamma X_{t}+e_{t}
$$

where $F D$ is the financial development indicator, $X$ is a vector of control variables, and $e$ is an error term that is serially uncorrelated, with zero mean and constant variance.

It is usually difficult to identify proxies that measure adequately the financial development. Previous studies used different indicators that capture the size, activity and efficiency of the financial sector, banks or markets. The reform of the financial sector in Lebanon started in the early nineties and included the banking sector and the stock market simultaneously. Consequently, the banking sector has turned rapidly into one of the most 
dynamic sectors of the economy. However, the stock market stayed behind and couldn't play the expected role. Given this lack in development and data unavailability on the stock market of Beirut that covers the sample period, our study will rely on the banking sector to measure the financial development.

Thus, in this study we consider three indicators, the ratio of credit to the private sector to GDP as a measure of financial depth, ratio of liabilities of banking deposits to GDP as an indicator of the financial depth and the overall size of the financial intermediation sector, and the ratio of bank claims on private sector to domestic credit.

Three indicators of economic growth were suggested by Levine (1997): real GDP per capita growth, average capital stock per capita growth, and productivity growth. In our analysis, we use logarithm of real GDP per capita as indicator of economic growth. Other control variables are supposed to influence the economic growth and are introduced in our model, including, the spread between deposit and lending rates (or interest rate margin) as proxy for banking efficiency, and the ratio of government expenditure to GDP, the ratio of investment to GDP, the ratio of openness to GDP. The last three variables are expressed in logarithmic form.

The investment is proxied by the gross fixed capital formation, and openness was measured by the ratio of the sum of import and export to GDP.

The time series studies for individual countries allow us to test for the lead-lag relationship between variables. Our study is based on cointegration and applies vector error correction method for testing Granger causality (1980) or lead-lag relationship. Thus, after examining the unit-root tests using Augmented Dickey-Fuller and Phillips-Peron tests we determine the order of the VAR using Akaike's Information Criterion. Then we apply the Johansen cointegration tests (1991) to identify the long-run equilibrium relationship, if it sexists. The presence of such relationship rules out spurious relationship among the variables. Afterwards, we apply the vector error correction model and use it to indicate the direction of Granger causality in both the short and long run.

The vector error correction model is expressed as follows:

$$
D Y_{t}=\mu+\Gamma_{1} D Y_{t-1}+\cdots+\Gamma_{p-1} D Y_{p-1}+\alpha E C M_{t-1}+\epsilon_{t}
$$

where $\mathrm{D}$ is a difference operator and $\mathrm{Y}$ is a vector of vector of $\mathrm{I}(1)$ variables that are involved in this study, $\epsilon_{t}$ is a vector of white noise errors, ECM is the residuals of the long-run model lagged one period, and $\alpha$ is a vector of adjustment coefficients. These latter indicate the adjustment to long-run equilibrium. They should be statistically significant and have a negative sign. The Granger causality among these variables is tested through the vector error correction model.

\section{Data and Variables Description}

This study investigates empirically the effects of financial sector development on economic growth over the period 1972-2012.

Financial development is usually defined as a process that enhances the quality, quantity, and efficiency of financial intermediary services. The performance of this process depends on many activities and institutions. Therefore, it cannot be captured by one measure.

The choice of appropriate indicators of financial development is a difficult task due to the diversity of financial services provided by the financial sector (Ang, 2007; Ang \& McKibbin, 2005). These measures concern usually the banking sector and the stock market. However, Huw Pill and Mahmood Pradan, (1997) suggest "In most developing nations, the banking industry dominates the financial structure and securities are not well developed."

The domestic capital markets remain underdeveloped and lack significant diversification. It includes only seven banks, Solidaire (a company in charge of rebuilding and managing Beirut's city center), and Hocim (a cement company). The domestic market of bonds is also considered to be under-developed since only government fixed income securities are listed in this market with very few corporate and banks that have recourse to bond issuing for debt funding. Given that this market is still underdeveloped and the data unavailability that covers the sample period, our study will be restricted on the banking sector only.

Different variables have been used in previous studies such as the ratio of M2 to GDP (Calderon and Liu, 2003; King and Levine, 1993). However, in developing countries (such as Lebanon) a large portion of M2 consists of currency held outside banks. Therefore, M2/GDP explains more the extent of monetization than the financial development (Khan \& Qayyum, 2006). To overcome this issue, some studies used, as a proxy for the financial development, the ratio of banking deposit liabilities (= M2-currency in circulation) to GDP (Demetriades and Hussein, 1996). 
In this study, the financial development is measured by three variables: the first measure is the ratio of banking deposit liabilities to GDP. The second measure is the ratio of claims of banks on the private sector to nominal GDP. This ratio has been commonly used in many studies such as Beck, Levine (2000) and Demetriades and Hussein (1996) among others. It is assumed to reflect the quantity and efficiency of investment and consequently the economic growth. The third measure used in this study is the ratio of private sector credit to domestic credit which allows capturing the distribution of credit between private and public sectors.

To avoid some econometric problems such as over-parameterizations and possible problem of multicollinearity since these variables may be highly correlated, we will construct an index (denoted FACTOR) for financial development following the approach of Demetriades and Luintel (1997, 2001) and Ang and McKibbin (2007). Using these three variables, a summary measure of financial development, which represents the joint impact of the selected financial indicators, is developed by using the method of principal component analysis. This index is supposed to capture most of the information from the underlying dataset pertaining to the three variables.

Table 1. Principal component analysis for the financial development index

\begin{tabular}{cccc}
\hline Principal component & Value & Proportion & Cumulative Proportion \\
\hline 1 & 1.773219 & 0.5911 & 0.5911 \\
2 & 0.940569 & 0.3135 & 0.9046 \\
3 & 0.286212 & 0.0954 & 1.0000 \\
\hline & & Eigenvector & \\
Variable & PCI & PC2 & PC3 \\
\hline$L I B G$ & 0.692829 & 0.003271 & 0.721095 \\
$P S D C$ & -0.501005 & 0.721402 & 0.478094 \\
$P S G$ & 0.518635 & 0.692509 & -0.501447
\end{tabular}

Note. $L I B G=$ ratio of bank deposits liabilities to GDP, $P S D C=$ ratio of claims on private sector to domestic credit, and $P S G=$ claims on private sector to GDP.

Table 1 reports the results obtained from principal component analysis. The eigenvalues indicate that the first component explains $59.11 \%$ of the standardized variance. The second principal component explains another $31.35 \%$ and the third component explains $9.54 \%$. These percentages of variances are used as weights to compute the index of financial development.

In line with the standard practice, we used real GDP per capita (at 2005 constant prices) to measure the economic growth in Lebanese pounds. In addition, we used some macroeconomic variables that have major influence on economic growth in Lebanon. These variables are: investment (which proxied by the gross fixed capital formation) as share of GDP, openness which is measured by the sum of import and export as share of GDP, government expenditure as share of GDP, and interest rate margin which calculated by subtracting the deposit rate from the lending rate. All variables are expressed in logarithmic form, except for the margin and the investment as share of the GDP.

Our model includes two dummy variables D1 and D2. The former is used to account for the period of financial sector development policies that launched in 1993. This variable takes the value 0 for the period before 1993 and 1 afterwards. The latter is employed to take into account the civil war that lasted from 1975 to 1989. This variable takes the value 0 during wartime and 1 during peacetime. The description of these variables is presented in table 2.

We used annual data covering the period from 1972 to 2012 . The data are collected from different sources. The financial development measures, deposit rate were calculated from International Financial Statistics (IFS) data. The real GDP per capita, openness, and investment are calculated from the World Development Indicators (WDI). Government expenditures were taking from the ministry of finance in Lebanon and the interest rate margin was calculated form data in the Central Bank. 
Table 2. Description of variables

\begin{tabular}{ll}
\hline$L R G D P P C$ & is the logarithm of real annual per capita gross domestic product in Lebanon (at prices of 2005) \\
LO & is the logarithm of the ratio of openness to nominal GDP \\
LIRM & is the logarithm of interest rate margin \\
LEXPG & is the logarithm of the ratio of government expenditure to nominal GDP \\
$I N V G$ & is the ratio of investment to nominal GDP \\
$I N D E X$ & is the factor obtained from the factor analysis involving ratio of bank claims on private sector to nominal GDP, ratio \\
& of domestic credit, and ratio of bank claims on private sector to domestic credit \\
is a dummy variable that takes 0 in the wartime, i.e. for the period between 1975 and 1989, and 1 in the peacetime \\
otherwise.
\end{tabular}

\section{Empirical Results}

The empirical part of this study starts by diagnosing the data using tests such as unit root tests and Johansen co-integration test. Consequently, an appropriate vector error correction model (VECM) is constructed based on annual data over the period 1972-2012. This model provides the long-run equilibrium relationship and the short-run dynamics. Then we conduct VECM-based Granger causality tests in order to identify the direction of causally among the variables in question, if it exists.

\subsection{Testing for Unit Roots}

The first step is to determine the order of integration of the variables involved in this study. To do so, we apply Augmented Dickey-Fuller $(1979,1981)$ and Philips-Perron (1988) tests for unit root. The results reported in table 3 show that all variable are non stationary at their levels, but they are stationary at their first difference. Thus, these variables are integrated of order 1, i.e. I(1).

Table 3. Results of unit root tests using Augmented Dickey-Fuller (ADF) and Fillips Perron (PP) tests

\begin{tabular}{lcccccc}
\hline & & \multicolumn{3}{c}{ ADF } & \multicolumn{2}{c}{ PP } \\
Variables & lag & Level & lag & First difference & Level & First difference \\
\hline LRGDPP & 1 & -1.15753 & 0 & $-3.45348^{* *}$ & -0.99366 & $-3.41671^{* *}$ \\
LOPN & 0 & -1.85796 & 0 & $-6.78368^{* * *}$ & -1.92330 & $-6.75953^{* * *}$ \\
LIRM & 1 & -1.71099 & 0 & $-3.98547^{* *}$ & -1.21920 & $-3.94402^{* *}$ \\
LEXPG & 0 & 0.20383 & 3 & $-4.25169^{* * *}$ & 0.31552 & $-6.70252^{* * *}$ \\
$I N V G$ & 0 & -2.070829 & 0 & $-7.282513^{* * *}$ & -2.007807 & $-7.277683^{* * *}$ \\
$I N D E X$ & 6 & -2.11668 & 3 & $-4.36833^{* * *}$ & -2.71072 & $-8.13859^{* * *}$ \\
\hline
\end{tabular}

Note. ${ }^{*}, *$, and $* *$ indicate significance at $10 \%, 5 \%$, and $1 \%$ respectively or the rejection of the null hypotheses of unit root at these levels.

\subsection{Testing for Cointegration}

Table 4. Cointegration test results

\begin{tabular}{ccccc}
\hline Null Hypothesis & Alternative Hypothesis & Test Statistic & 0.05 Critical Value & Probability \\
\hline \multicolumn{5}{r}{$\lambda_{\text {Trace }}$ value } \\
$r \leq 1$ & $r>0$ & $120.1099^{* * *}$ & 95.75366 & 0.0004 \\
$r \leq 2$ & $r>1$ & 62.65915 & 69.81889 & 0.1630 \\
$r \leq 3$ & $r>2$ & 36.81847 & 47.85613 & 0.3561 \\
$r \leq 4$ & $r>3$ & 18.40816 & 29.79707 & 0.5360 \\
$r \leq 5$ & $r>4$ & 3.942235 & 15.49471 & 0.9081 \\
\hline$r>5$ & 0.696283 & 3.841466 & 0.4040 \\
\hline$r=0$ & $r>0$ & $\lambda_{\max }$ eigenvalue & \\
$r=1$ & $57.45076^{* * *}$ & 40.07757 & 0.0002 \\
$r=2$ & $r=1$ & 25.84068 & 33.87687 & 0.3305 \\
$r=2$ & 18.41031 & 27.58434 & 0.4613 \\
& $r=3$ & 14.46592 & 21.13162 & 0.3280 \\
\hline
\end{tabular}




\begin{tabular}{lllll}
\hline$r=3$ & $r=4$ & 3.245952 & 14.26460 & 0.9290 \\
$r=4$ & $r=5$ & 0.696283 & 3.841466 & 0.4040 \\
\hline
\end{tabular}

Note. Trace and max-eigenvalue tests indicate 1 cointegrating equation at the 0.01 level of significance. $r$ indicates the number of cointegrating vectors and $\lambda_{\text {trace }}$ and $\lambda_{\max }$ are tests statistic of trace and maximum eigenvalue tests respectively.

Since the variables in question are I(1), the second step is to proceed with the cointegration test using Johansen procedure that encompasses two tests, Trace test and Maximum Eignvalue test. These tests are performed to explore the presence of a long-run equilibrium relationship among the variables. If the variables are cointegrated, then a long-run equilibrium relationship among the variables exists. The results of the tests are presented in table 4. We notice that Trace and Maximum Eigenvalue statistics indicate the existence of one cointegrating vector.

\subsection{Long and Short Run Models}

The presence of cointegration is indicative of a long term relationship between the real GDP per capita, the financial development, margin, openness, government expenditure, and investment. The application of the vector error correction modeling technique leads to the obtaining of long and short run models. These later are reported in table 5 and 6 respectively.

Table 5. Long term model of financial development and economic growth

\begin{tabular}{|c|c|c|c|}
\hline \multicolumn{4}{|c|}{ Dependent variable: $L R G D P P$} \\
\hline \multicolumn{4}{|c|}{ Sample (adjusted): 1974-2012 } \\
\hline Variable & Coefficient & Standard Error & $t$-Statistics \\
\hline C & $28.70901 * * *$ & 11.0041 & 2.83071 \\
\hline$L O P N G$ & $-21.36353 * * *$ & 3.19466 & -6.68727 \\
\hline LIRM & $-4.94990 * * *$ & 1.12415 & -4.40326 \\
\hline$L E X P G$ & $16.42277 * * *$ & 2.17476 & 7.55152 \\
\hline$I N V G$ & $0.61522 * * *$ & 0.10456 & 5.88373 \\
\hline$I N D E X$ & -2.193628 & 1.34570 & -1.63010 \\
\hline
\end{tabular}

Note. ${ }^{*}, *$, and $* *$ indicate significance at $10 \%, 5 \%$, and $1 \%$ respectively.

The results in table 5 indicate that all variables are highly significant (at $1 \%$ level of significance), except for the index of financial development. This latter appears to be not significant in the long run. The openness is statistically significant and has a negative effect on economic growth. This may be attributed to the fact that Lebanon is characterized by an import-dependent economy. Most of the imported goods are not addressed to productive activities. They are mostly addressed to services and final consumption. The reliance of the Lebanese economy on the outside has made it vulnerable to changes in the international market prices. Thus any inflation is automatically transferred to the Lebanese economy resulting in a negative effect on growth. Consequently, the high propensity to import of Lebanon, with no significant increase in the exports, results in a drain on foreign exchange and a shrinking of the economy.

The investment has an expected positive and significant effect on economic growth. As to government expenditure, although it increases the budget deficit and the public debt, it has a positive impact on economic growth since the accumulated sums spent by the government on the rehabilitation and reconstruction can be reflected by a positive impact on growth in the long run. The margin shows a negative and statistically significant impact on economic growth, indicating that a tightening reform policy, progressively, over time, generally reduces margins and therefore encourages investment which is reflected by an enhancement of the economic growth. A significant improvement in the efficiency of the financial system is measured by significant decrease in interest rate margins. The negative and significant sign of the interest rate margin is consistent with the theory (see Harrison et al.,1999) which indicates that a shrinking interest rate margin can increase economic growth. 
Table 6. Error correction model of financial development and economic growth

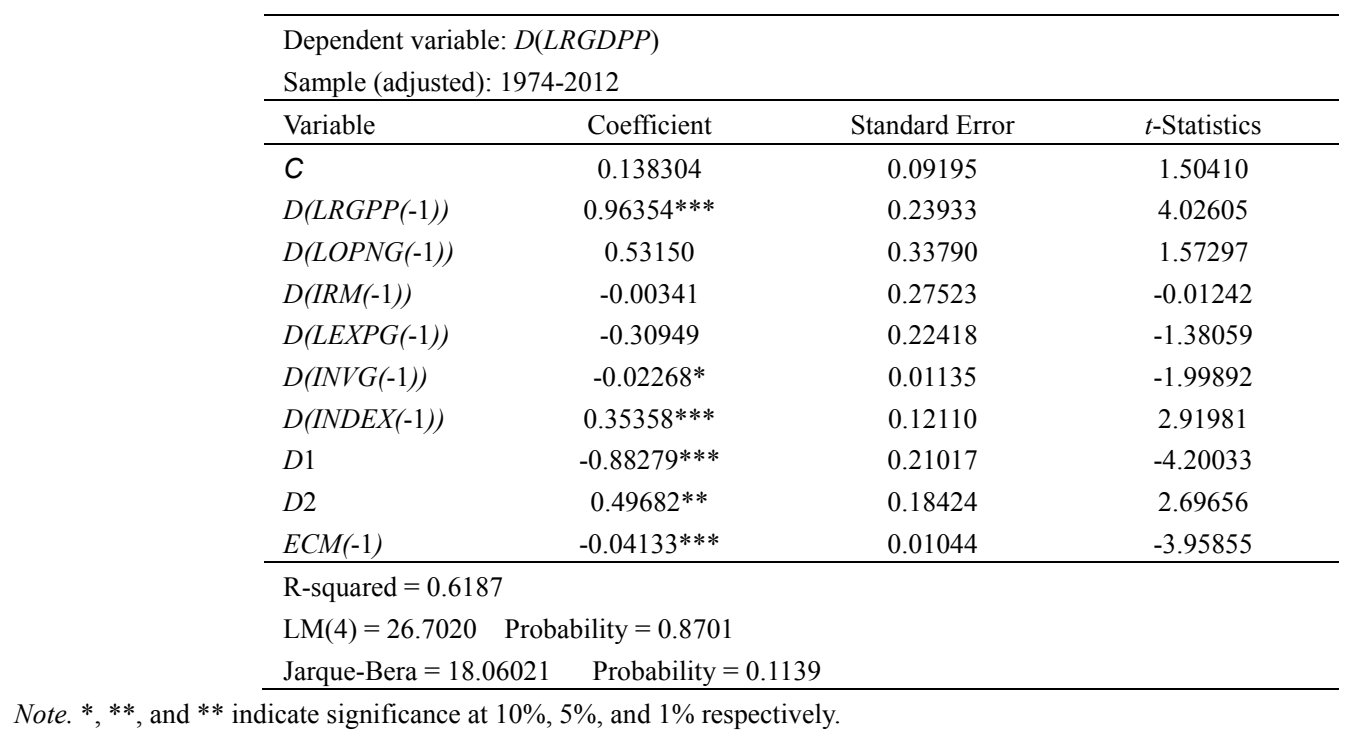

The findings in table 6 relative to the short run model indicate that the error correction coefficient $(E C M)$ is negative and significant at $1 \%$ level of significance. This means that deviation of the variables from the long run equilibrium has a speed of adjustment at the rate of about $4 \%$ annually. Moreover, we notice that the index of financial development is positive and highly significant (at $1 \%$ level) in the short run. It is important to mention that the presence of foreign banks has helped to the development of the financial sectors by assuring the technology transfer and increasing the competition. They have been more innovative in terms of the number and range of new products offered, some of them already available in the foreign banks' home markets. Moreover, the conservative policies adopted by financial authorities have kept the banking sector from major crisis that could affect the economy. As a result, banking sector has played a positive role in the development of the Lebanese economy. Moreover, the positively significant coefficient of the index indicates that the more stable are the banks the more positively impact the economic growth. The financial reform and the improvement in the structure of the financial institutions appear to be closely related to economic growth. The margin is statistically significant and has a negative sign which is in line with the results obtained in previous studies. These latter show that different aspects of financial liberalization are related to considerable reductions in margin.

As to the investment it appears to have a negative sign and to be significant at $10 \%$ level in the short-run. This negativity may be attributed to the fact that the majority of investments are not addressed to productive activities. They are mainly directed to services that impact the nature of the economy in Lebanon. However, the accumulation of relatively small portions of investments that deal with productive activities has a positive impact on economic growth in the long run (see table 5). On the other hand, government expenditure, openness, margin showed insignificant relationship with economic growth in the short run. The government expenditure is high in Lebanon as percentage of GDP. However, if the service and debt payment are removed, this ratio goes down significantly. For this reason the government spending was found ineffective in the short run (World Bank, 2005a). The accumulation of the small portions of contributions of the government spending shows its positive The dummies, used to account for the period of reforms and deregulation $(D 1)$ on one hand and the wartime and peacetime $(D 2)$ on the other hand, are significant but show different signs. The latter indicates that the period of peacetime has a positive and significant impact on economic growth. As to the dummy related to the stage of reform, it reveals a negative and significant impact on economic growth. This is due to the fact that the reforms and deregulation started in the early 90 's with a high intensity which continued to evolve at a decreasing rate later on. This process of development was hampered by several political and security risks. This also explains the positive impact of the financial development in the short run and its insignificance in the long run. This effect vanishes over time mainly because of the regression of the intensity of the development.

The diagnostics of the general model concerning the tests for the presence of autocorrelation and for normality indicate that the model satisfies all the requirements. The results reported in table 7 show that there is no autocorrelation among the residuals up to lag 4. Moreoever, the Jarque-Bera test for normality indicate that the residuals are normally distributed since we cannot reject the null hypothesis of multivariate normality of the 
residuals (see Table 8).

Table 7. VEC residual serial correlation LM tests

\begin{tabular}{ccc}
\hline Lags & LM-Stat & Probability \\
\hline 1 & 47.95319 & 0.0879 \\
2 & 38.62317 & 0.3519 \\
3 & 41.70155 & 0.2367 \\
4 & 26.70205 & 0.8701 \\
\hline
\end{tabular}

Note. Null Hypothesis: no serial correlation at lag order h.

Table 8. VEC Residual Normality tests

\begin{tabular}{cccc}
\hline Component & Jarque-Bera & df & Probability \\
\hline Joint & 18.06021 & 12 & 0.1139 \\
\hline
\end{tabular}

Note. Null Hypothesis: residuals are multivariate normal.

Null Hypothesis: residuals are multivariate normal. Furthermore, we checked for the stability of the coefficient using the CUSUM and CUSUM SQUARE tests which show stable coefficients (see figure 1).
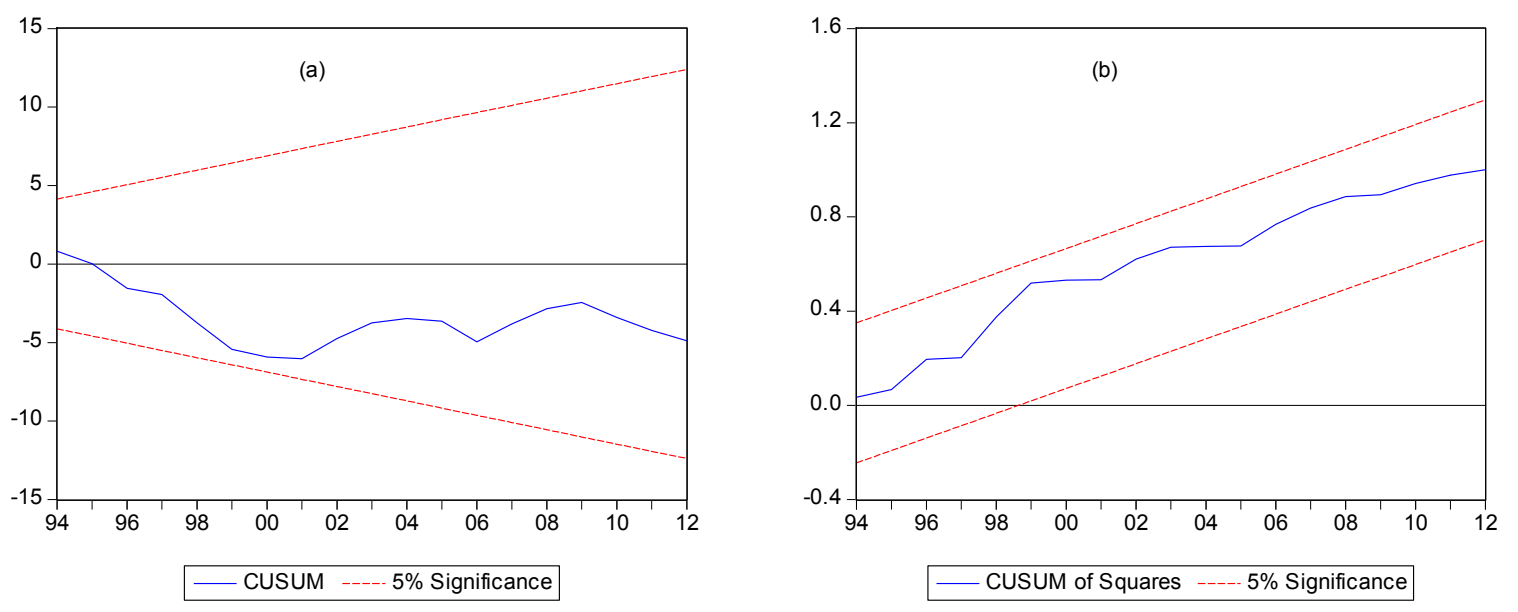

Figure 1. (a) Plot of cumulative sum of recursive residuals and (b) plot of cumulative sum of squares of recursive residuals

\subsection{Granger Causality Tests}

Table 9. The Chi-Square test results of long run and short run Granger causality among the variables in question

\begin{tabular}{|c|c|c|c|c|c|c|c|}
\hline \multirow[b]{2}{*}{$\begin{array}{l}\text { Dependent } \\
\text { variable }\end{array}$} & \multicolumn{6}{|c|}{$\begin{array}{l}\text { Short-run lagged differences } \\
\text { (asymptotic Granger } \chi^{2} \text {-statistics) }\end{array}$} & \multirow{2}{*}{$\begin{array}{c}\begin{array}{l}\text { Error term } \\
\text { coefficient }\end{array} \\
\boldsymbol{E C M}(-\mathbf{1})\end{array}$} \\
\hline & $D(L R G D P P)$ & $D(L O P N)$ & $D(L N I M)$ & $D(L E X P G)$ & $D(I N V G)$ & D(INDEX) & \\
\hline$D(L R G D P P)$ & & 2.47422 & 0.00015 & 1.90601 & $3.99566 * *$ & $8.52530 * * *$ & $-0.04133 * * *$ \\
\hline$D(L O P N)$ & 0.70682 & & 0.27055 & 2.79144* & 0.01518 & 0.06071 & 0.00177 \\
\hline$D(L N I M)$ & 1.74272 & $9.05936 * * *$ & & $6.44169^{* *}$ & $14.36075^{* * *}$ & 0.17927 & $-0.02839 * * *$ \\
\hline$D(L E X P G)$ & $13.50685 * * *$ & 1.58251 & 1.60051 & & $5.26459 * *$ & $4.08962 * *$ & 0.04174 \\
\hline$D(I N V G)$ & 0.89652 & 0.65749 & 0.00123 & 0.00015 & & 1.80066 & -0.12470 \\
\hline$D(I N D E X)$ & $0.39860 *$ & $4.09862 * *$ & 0.02699 & 0.01559 & 0.39860 & & 0.04296 \\
\hline
\end{tabular}

Note. ${ }^{*}, *$, and ${ }^{* *}$ indicate significance at $10 \%, 5 \%$, and $1 \%$ respectively. 
Error correction models help us to distinguish between the short run and long run Granger causality. The error correction model represents the long term relation among the variables. The effect of each variable in the short run is provided by the Chi-Square test of the joint differenced variables. The outcomes of these tests are summarized in table 9.

Error correction models help us to distinguish between the short run and long run Granger causality. The error correction model represents the long term relation among the variables. The effect of each variable in the short run is provided by the Chi-Square test of the joint differenced variables. The outcomes of these tests are summarized in table 9.

The results indicate the presence of bidirectional causality between financial development and economic growth which is in line with previous study that found similar results such as Jung (1986) and Demetriades and Hussein (1996).

Moreover, there is evidence of unidirectional causality that runs, $i$ ), from GDP to investment, $i i$ ) from openness to government expenditure, iii) from margin to openness, government expenditure, and investment, iv) from government expenditure to GDP, investment, and financial development, and finally, $v$ ) from financial development to openness.

However, the investment does not Granger cause any of the variables in the model.

\section{Conclusion}

The Lebanese economy had suffered from many wars and political events that hampered its growth for several periods till 2007. Moreover, the poor provision of infrastructure, especially electricity, could be one of the main factors of slow growth.

The 2008 financial crisis led to a sharp retreat of private credit in many countries. In contrast, credit surged in Lebanon from an already higher base than the median compared to other countries. It was a golden period for the Lebanese banks. The private sector credit growth was about 20 percent per year during 2008-2010, which is higher than the average 6\% a year during 2005-2007. The credit growth in 2008-2010 was mainly concentrated in trade and services, household loans, and the construction sector. This letter boosted remarkably during this period. The mentioned sectors profited from $80 \%$ of all new loans since 2008. As a result, this crisis and its economic repercussions had positive effects on the Lebanese economy during the period 2008-2010. Thereafter, the economic growth, affected by the national and regional events, retreated significantly during the period 2011-2012.

The banking sector has contributed remarkably and since a long time to finance a significant portion of the needs of the public sector even if the volume of this funding varies from one period to another depending on various factors including, available liquidity of banks and the needs of public sector financing.

The stability of the banking sector in Lebanon is mainly attributed to the prudential and supervising policy adopted by the financial authorities. After a series of deregulations and reforms, it was important to investigate the role that plays the financial system on the economic growth through a VECM technique over the period 1972-2012. Then we tested for the causality and its directions. We introduced some macroeconomic variables such as margin, investment, government expenditure, and trade. These three last variables were taken as share of the GDP. All variables were expressed in logarithmic form, except for margin and investment. The financial variables that are used to express the development of the financial system are the ratio of claims on private sector to GDP, ratio of claims on private sector to domestic credit, and the ratio of banking deposits liabilities to GDP. An index composed of these variables is constructed using principal component technique. The results show that there is a positive relationship between financial development and growth in the short run, but this relation is not significant in the long run. Moreover, the Granger causality test revealed the presence of bidirectional causality between financial development and economic growth.

As a result, there is mutual interaction between financial sector and economic growth. The former leads the economic growth by successfully identifying profitable projects that could be funded. Moreover, a well functioning financial system would stimulate technological improvements since it has the ability to select and finance businesses that are expected to be successful. Hicks (1969) and Bagehot (1973) stipulated that industrialization in England was mainly financed by funds from the financial sector which was in period of remarkable development. The latter spur the financial sector to develop its policies and promote innovations in order to satisfy the requirements of the economic enhancement. 


\section{Acknowledgement}

This project has been funded with support of the European Commission. This publication (communication) reflects the view only of the author, and the Commission cannot be held responsible for any use which may be made of the information contained therein.

\section{References}

Abu-Bader, S., \& Abu-Qarn, A. (2006). Financial Development and Economic Growth Nexus: Time Series Evidence from Middle Eastern and North African Countries. Working Papers 223, Ben-Gurion University of the Negev, Department of Economics.

Achy, L. (2005). Financial Liberalization, Savings, Investment, and Growth in MENA Countries. In S. Neaime $\&$ N. A. Colton (Eds.), Money and Finance in the Middle East: Missed Opportunities or Future Prospects? (Research in Middle East Economics (Vol. 6, pp. 67-94). Emerald Group Publishing Limited.

Ang, J. B., \& McKibbin, W. J. (2005). Financial liberalization, financial sector development and growth: evidence from Malaysia. Brookings Discussion Papers in International Economics, 168, 1-29.

Ang, J. B., \& McKibbin, W. J. (2007). Financial Liberalization, Financial Sector Development and Growth: Evidence from Malaysia. Journal of Development Economics, 84, 215-233. http://dx.doi.org/10.1016/j.jdeveco.2006.11.006

Apergis, N., Filippidis, I., \& Economidou, C. (2007). Financial deepening and economic growth linkages: A panel data analysis. Review of World Economics, 143(1), 179-198. http://dx.doi.org/10.1007/s10290-007-0102-3

Arestis, P., Demetriades, P. O., \& Luintel, K. B. (2001). Financial Development and Economic Growth: The Role of Stock Markets. Journal of Money, Credit, and Banking, 33(1), 16-41. http://dx.doi.org/10.2307/2673870

Bagehot, W. (1873). Lombard Street (1962 ed.). Homewood, IL: Richard D. Irwin.

Beck, T., Levine, R., \& Loayza, N. (2000). Finance and the sources of growth. Journal of Financial Economics, 58, 261-300. http://dx.doi.org/10.1016/S0304-405X(00)00072-6

Ben Naceur, S., \& Omran, M. (2008). The Effects of Bank Regulations, Competition and Financial Reforms on MENA Banks' Profitability. Working Papers, 449, Economic Research Forum, revised Oct 2008. Retrieved from http://www.erf.org.eg/CMS/getFile.php?id=1345

Calderon, C., \& Liu, L. (2003). The direction of causality between financial development and economic growth. Journal of Development Economics, 72, 321-334. http://dx.doi.org/10.1016/S0304-3878(03)00079-8

Cline, W. R. (2010). Financial globalization, economic growth, and the crisis of 2007-2009. Washington, D.C.: Peterson Institute for International Economics.

Demetriades, P. O., \& Hussein, K. A. (1996). Does financial development cause economic growth? Time-series evidence from 16 countries. Journal of Development Economics, 51, 387-411. http://dx.doi.org/10.1016/S0304-3878(96)00421-X

Demetriades, P. O., \& Luintel, K. B. (1997). The Direct Costs of Financial Repression: Evidence from India. Review of Economics and Statistics, 79(2), 311-320. http://dx.doi.org/10.1162/003465397556665

Dickey, D. A., \& Fuller, W. A. (1979). Distributions of the Estimators for Autoregressive Time Series With a Unit Root. Journal of American Statistical Association, 74, 427-431.

Dickey, D. A., \& Fuller, W. A. (1981). Likelihood Ratio Statistics for Autoregressive Time Series With a Unit Root. Econometrica, 49, 1057-1072. http://dx.doi.org/10.2307/1912517

Ghali, K. (1999). Financial Development and Economic Growth: The Tunisian Experience. Review of Development Economics, 3(3), 310-322. http://dx.doi.org/10.1111/1467-9361.00070

Goldsmith, R. W. (1969). Financial structure and development. New Haven, CT: Yale U. Press.

Granger, C. W. J. (1980). Testing for causality: A personal viewpoint. Journal of Economic Dynamics and Control, 2, 329-352. http://dx.doi.org/10.1016/0165-1889(80)90069-X

HICKS, J. (1969). A theory of economic history. Oxford: Clarendon Press.

Johansen, S. (1991). Estimation and hypothesis testing of cointegration vectors in Gaussian vector autoregressive models. Econometrica, 59, 1551-1580. http://dx.doi.org/10.2307/2938278

Jung, W. S. (1986). Financial Development and Economic Growth: International Evidence. Economic 
Development and Cultural Change, 34, 336-346. http://dx.doi.org/10.1086/451531

Kar, M., \& Pentecost, E. J. (2000). Financial Development and Economic Growth in Turkey: Further Evidence on the Causality Issue. Economic Research Paper No.00/27, Department of Economics, Loughborough University.

Khan, M. A., \& Qayyum, A. (2006). Trade Liberalisation, Financial Sector Reforms, and Growth. The Pakistan Development Review, 45(4), 711-731.

King, R. G., \& Levine, R. (1993). Finance and Growth: Schumpeter Might be Right. Quarterly Journal of Economics, 108, 717-737. http://dx.doi.org/10.2307/2118406

Levine, R. (1997). Financial Development and Economic Growth: Views and Agenda. Journal of Economic Literature, 35, 688-726.

Levine, R. (2005). Finance and Growth: Theory and Evidence. Handbook of Economic Growth. In P. Aghion \& S. Durlauf (Eds.), Handbook of Economic Growth (1st ed., Vol. 1, Chapter 12, pp. 865-934). Elsevier. http://dx.doi.org/10.1016/S1574-0684(05)01012-9

Levine, R., \& SARA, Z. (1996). Stock Markets, Banks, and Economic Growth. World Bank Policy Research Working Paper, No. 1690.

Levine, R., Loayza, N., \& Beck, T. (2000). Financial intermediation and growth: causality and causes. Journal of Monetary Economics, 46, 31-77. http://dx.doi.org/10.1016/S0304-3932(00)00017-9

Lucas, R. E. (1988). On the Mechanics of Economic Development. Journal of Monetary Economics, 22(1), 3-42. http://dx.doi.org/10.1016/0304-3932(88)90168-7

Luintel, K. B., \& Khan, M. (1999). A quantitative reassessment of the finance-growth nexus: evidence from a multivariate VAR. Journal of Development Economics, 60, 381-405. http://dx.doi.org/10.1016/S0304-3878(99)00045-0

Manning, M. J. (2003). Finance Causes Growth: Can We Be So Sure? Contributions to Macroeconomics, 3(1), 1-22. http://dx.doi.org/10.2202/1534-6005.1100

Odhiambo, N. M. (2009). Interest rate liberalization, financial deepening and economic growth in South Africa: An empirical investigation. Paper Presented at the Ninth Annual IBER \& TLC Conference Proceedings, Las Vegas, NV, USA.

Phillips, P., \& Perron, P. (1988). Testing for a unit root in time series regression. Biometrica, 75, 333-346.

Pill, H., \& Pradhan, M. (1994). Monetary Aggregation: A Reconciliation of Theory and Central Bank Practice. IMF Working Paper, 94/118 (Washington: International Monetary Fund).

Robinson, J. (1952). The Generalization of the general theory in the rate of interest, and other essays (pp. 67142). London: Macmillan.

Schumpeter, J. A. (1911). The Theory of Economic Development. Cambridge, MA: Harvard University Press.

World Bank. (2005a). Public Expenditure Reform Priorities for Fiscal Adjustment, Growth and Poverty Alleviation. June, Washington D.C.

Zang, H., \& Kim, Y. C. (2007). Does financial development precede growth? Robinson and Lucas might be right. Applied Economic Letters, 14, 15-19. http://dx.doi.org/10.1080/13504850500425469

\section{Notes}

Note 1. Ministry of Finance reports: 1992-2012 and Central bank reports: 1972-2012.

Note 2. World Bank (IBRD and IDA): Overview, Bank Information Center, November 13, 2009.

Note 3. Central Bank and Association of Lebanese banks reports: 1972-2012.

Note 4. The Central Bank and The Banking Control Commission (BCC) have concluded a phase-in arrangement for the implementation of Basel III in Lebanon that is published in December 2011. 


\section{Copyrights}

Copyright for this article is retained by the author(s), with first publication rights granted to the journal.

This is an open-access article distributed under the terms and conditions of the Creative Commons Attribution license (http://creativecommons.org/licenses/by/3.0/). 